\title{
Speaking the Same Language? Gender-Based Teacher Performance in the EFL Class
}

\author{
Daniel Madrid* and Stephen P. Hughes
}

Universidad De Granada, Campus Universitario de Cartuja, 18071 Granada, Spain

\begin{abstract}
The concept of the modern-day teacher and the development of ideas such as 'teacher professionalism' have historically been gendered, often reflecting male paradigms and political theories. At the same time, there is a large body of research which shows that gender is a relevant variable which must be taken into account when explaining the functioning of classes and teacher-student interaction. This study aims to investigate the influence of teacher gender on students of English as a foreign language (EFL) in southern Spain and provides qualitative and quantitative evidence collected from students $(n=459)$ and teachers $(n=35)$ from primary school through to university levels which challenges some of these gendered paradigms and provides contrasts with previous studies on preferences of teacher gender. Our contextualised investigation provides evidence to suggest that the construction of more supportive and democratic learning environments are more frequently observed in our specific context among female teachers, while more prescriptive environments traditionally associated with masculinized forms of teaching are perceived as being less helpful in obtaining successful learner outcomes.
\end{abstract}

Keywords: Language learning, EFL, teacher gender, gender-based performance.

\section{INTRODUCTION}

In the socio-educational field, it has often been argued that the epistemolological premises of teacher professionalism are rooted in a profoundly male concept of gender politics. This is reflected in the Cartesian and Kantian notion of the instructor as 'a rational and instrumental actor', which serves as a reference point for the concept of the modern day teacher. For Dillabough [1], gender and the history of male domination in political thought are crucial if we are to understand the traits of modern-day schooling. This contemporary notion of professionalism is conceived as the rational capacity to behave in a competent and efficient way in order to obtain an adequate level of effort from students; thus the professional teacher contributes to the attainment of objectives proposed by the neo-liberal democracy and thereby encourages desired social and economic change; such developments have the potential to undermine teachers' political authenticity and can essentially lead to forms of technical control (p. 375).

The feminist alternative attempts to remove the gender determinism of political theory and the stereotypes of the 'rational and competent teacher', arguably laid down by the governments since, it is argued, they constitute a gendered model of both professionalism and the teacher. It aims to break away from a tradition which has considered the instructor as a rational and instrumental actor or agent who takes on a model of reason as the only true paradigm, in which masculinity and service to power play a fundamental role. In its place, a concept of the teacher is proposed that is more in accordance with social constructivism.

*Address correspondence to this author at the Universidad De Granada, Campus Universitario de Cartuja, 18071 Granada, Spain; Tel: 34958 243965; Fax: 34958 244187; E-mail: dmadrid@ugr.es
However, while steps are being taken to raise awareness of the gender factor in teaching and learning and although certain progress has been made, in practical terms, traditionally gendered views on instruction still lead to the undervaluing of the profession itself and even bring about a questionable gender-based distribution of teachers at certain academic levels (see [2]). Furthermore, current trends in effectiveness and performance management in education appear to be remasculinising already gendered policies. As a number of authors suggest [3, 4] many elements employed both in the philosophy and within the very discourse of educational performance management are discriminatory.

In Spain, recent legislative changes have introduced mechanisms aimed at removing gender bias, while at the same time instigating nation-wide programmes to enhance the quality of education based on performance management strategies previously employed in other EU countries. As mentioned, however, the nature of the latter has arguably contributed to a remasculinisation of the teaching profession in other contexts. Thus, it is posited here that the possible benefits that may be obtained by these trends may be detrimental to those social aspects which educational administrations theoretically strive to offer, including that of gender equity.

While taking into consideration these changes in the Spanish education system, this study attempts to address a number of questions related to how the gender factor influences the interaction and perspectives which exist between teachers and students in the EFL class and aims to identify which characteristics are most closely associated with improved student satisfaction and performance. 


\section{STUDIES ON GENDER IN TEACHING AND LEARN- ING}

There are several important studies which prove that gender, on the part of both the teacher and the student, is a relevant variable that must be taken into account when explaining the functioning of classes and the types of interaction which occur therein. For example, McAuliffe [5] and Kamler [6] found that the characters depicted in pieces of written work carried out by students often reflect certain gender stereotypes. Furthermore, in examining group discussions among students, Evans [7] has shown that there is an abundance of individual beliefs on gender domination and subordination which allows some people to be heard more than others. A number of these studies are supported by research in ELT. For example, it has been shown that male language learners tend to dominate conversations and produce more language output; female students, on the other hand, tend to initiate more conversations and receive more input [8].

In many educational contexts gender stereotyping has been shown to exist not only among teachers and learners but also in the elaboration of classroom materials, including textbooks [9] and, more recently, in educational software for young children [10]. Language teaching has also had its share of stereotyping and, indeed, bias, as we can observe in Leskin's [11] examination of popular ESL textbooks. As in other subject areas, the use of gender biased resources, which are often widely accepted by teachers, essentially leads to systematic and often unconscious perpetuation of the inappropriate treatment of gender in teaching and learning. It has been noted that unless appropriate steps are taken to raise awareness of practices such as gender stereotyping and, indeed, to rectify them, students are likely to reproduce them [12].

\section{Gender Policies}

Gender stereotyping and domination are areas which are often filled with controversy. Various educators, for example believe that the socialisation of gender roles is primarily a function which should be addressed at home with the family; consequently, the school should remain neutral. If we were to concur with this position, a natural conclusion would be to suggest that the school must treat all students equally, leaving freedom of choice in the adoption of roles. However, there are those who think that the school should not remain indifferent and argue instead for the promotion of behaviours which reflect the values of society and the school itself; this position would likely support the existence of a gender policy within schools.

Among the teachers who do endorse a gender policy there is a debate between those who are in favour of equity and those who defend equality. Those who support equality believe that all students must have equal opportunities to access resources and to participate in activities. Those who are in favour of equity believe that weaker groups must be favoured in order to increase their chances of reaching the same level as those in a more privileged position. This essentially represents a compensatory policy which encourages equality [13]. Both options are problematic, since there are those who do not feel comfortable treating groups of students in different ways, and others who consider it unfair to give the same treatment to different groups who do not have the same options open to them [12]. Perhaps the ideal solution would be a combination of equity and egalitarian practices whereby the same opportunities are given to all students and special attention given to groups with specific needs. Either way, it would appear that the construction of a gender policy in schools is of fundamental importance if we are to raise awareness of gender issues and to enable individual and groups of teachers and students to consciously prevent and challenge discriminatory behaviours.

\section{Teachers' Treatment of Gender Issues}

The way in which instructors approach gender related issues will very much depend on their own perceptions of gender. Some teachers, for example, believe that differences between male and female students are originated by purely biological motives, others attribute gender differences to socialisation processes, and there are a number of eclectics who attempt to combine the reasons from both sectors.

In terms of specific treatment of gender in the classroom, Alverman et al. [14] and Evans [7] have found that the teacher often attempts to strike a balance in debates with students about gender-related themes by introducing some points of view, without imposing them, and allowing students to adopt their own personal positions. In another study carried out with 1519 high school students, Commeyras et al. [15] discovered that $86 \%$ of teaching staff felt more at ease a) monitoring equal participation between boys and girls; and b) including the work of boys and girls who belonged to another lower level group in curricular tasks. At the same time, however, a large sector of the teaching staff felt uncomfortable debating controversial themes such as sexist language or the identification of students with characters of the same gender. This study reflects the teacher's interest in applying egalitarian gender strategies, but it also indicates that instructors may feel reluctant to deal with gender-related themes because of the controversy they produce.

\section{Gender and Teacher Behaviour}

In terms of teacher gender and its effect on students, research such as that conducted by Wilkinson and Marret [16] has shown that this variable must be taken into account when attempting to explain perceptions and behaviours in schools. As far as the gender factor and interaction between instructors and students is concerned, various studies indicate that boys and girls are treated differently by their teachers. Brophy [17] and Meece [18] have shown that teachers pay more attention to boys, give them more answers in public, praise them more frequently and criticise them more harshly when they under-perform or behave badly. Their research concludes that the differential behaviour of teachers is a consequence of gender differences in the behaviour of the students. The studies of Baumert [19] and Streitmatter [13] have also found that gender differences in students are related to and interact with academic success, interests, classroom behaviour, race and thematic content of subjects taught. Lawrenz [20] has indicated that, in secondary level education, girls perceive the psychological environment of the class to be more favourable when they have a male teacher, while the boys are more comfortable with a female teacher. Both the gender of the students and the teacher affect their mutual relationship in the classroom. 
With this general hypothesis in mind, Hopf and Hatzichristou [21] carried out studies in Greece with 1041 primary school students and 862 secondary school students in order to examine the extent to which teacher-student interaction is affected by teacher gender. Their results showed the existence of significant differences arising from the gender of the teacher when it comes to assessing student competence. Furthermore, female teachers tended to employ a greater number of gender stereotypes in their attitude and expectations with regards to student behaviour and frequently adopted stereotypical roles more closely associated with the female gender: they acted as maternal figures, showing a large degree of protection towards the children as well as greater understanding towards their bad behaviour. In secondary education the female teachers were more sympathetic to the problems of students who performed poorly and attributed a higher level of importance to the interpersonal problems of students than the male teachers. This behaviour has been reported in other investigations which have shown a higher degree of sensitivity towards student behavioural problems by female teachers (e.g. [22]), as well as Jones and Wheatley's [23] observation of their tendency to give more advice or warnings with regards to male students. At the same time, it is possible that male teachers control aggressive gestures, disobedience and indiscipline at the adolescent stage more easily than the female teachers, although the female teachers were shown to be more adept and effective at the primary level. It was also found that teachers assessed interpersonal problems between members of the opposite sex as being less problematic than those between members of the same sex, although this is a more difficult matter to interpret. Male teachers showed a more authoritarian and academically task-focused teaching style, while the female teachers showed a more expressive style, lent a greater degree of support towards the students and placed less emphasis on tasks, as seen in the work of Good, Sikes and Brophy [24].

Where student perceptions are concerned, Hopf and Hatzichristou's [21] study indicated that different aspects of student self-concept changed depending on the gender of the teacher: the self-concept of adolescents and their relationship with their classmates were more positive with teachers of the opposite sex. This view coincided with the perceptions of the teachers. Furthermore, it was observed that students from groups with a female teacher had a relatively higher, more positive self-concept in terms of physical appearance, academic achievement and their relationship with their parents than those who had a male teacher.

In Great Britain, Younger, Warrington and Williams [25] have also studied the variable of gender in relation to class interactions at secondary school level. Despite the fact that the teachers involved claim to treat boys and girls equally and while they say that little attention is paid to differences derived from gender, the results provided tend to show otherwise [25]. The first of a number of discrepancies mentioned in this study lies in the fact that girls academically outperform boys at Primary and Secondary levels [see 26, $27,28]$. Among the causes that could explain this difference, experts in the field point to the following: a greater lack of concern on the part of boys towards teacher authority, academic work and performance $[29,30]$; more negative attitudes towards work, and lower objectives and aspirations $[25,31]$, a greater degree of maturity and more effective learning strategies in girls [32]. Similar findings with regards to academic performance among girls have also been presented in literature on FL learning. In Britain, for example, in 1999 the Office for National Statistics pointed to the fact that girls consistently outperform boys in GCSE and A level examinations in modern languages [33]. Among the reasons for the differences in outcomes in language learning, girls appear to have more a more positive attitude towards language learning [34] while boys may have a tendency to see language subjects as being too feminine [33].

Younger, Warrington and Williams [31] also point out that boys behave in a different way from girls and, consequently, teachers treat them in a different way. Girls, for example, were better organised, they showed more sophisticated communicative skills, they had higher levels of selfconfidence and performed better in independent work sessions. The teachers perceived the girls as having a higher level of capacity for autonomous learning, a greater level of dedication to academic tasks at home and better planning of work. These differences in cognitive style have also been underlined by Head [35]. In contrast, boys were perceived in a more negative light:

many staff saw many boys as presenting an opposite image, more disordered, more demotivated, less willing to prioritise school work. (...) more vocal, more boisterous, less advanced for their years, more easily distracted than girls.

[30, p. 328]

Furthermore, male students were shown to be more concerned with their image within the group and were more likely to question both the type of education they received and the ethics of the school. Boys perceived that they received a more negative treatment from teachers than girls and they believed girls to be more astute, outwardly showing behaviour which they did not later put into practice. They approached male teachers and posed their problems in such a manner that they 'got their own way'. Girls, however, saw themselves in a more constructive light; they took the initiative more often and asked for clarifications more frequently.

While teachers may express that they pay little attention to gender differences in the classroom, a number of scholars, including Ropers-Huilman [36] and Weiler [37] have stated that teachers' identities do influence their teaching practice. Their own background and their status in relation to their gender affect the ways in which they construct their teaching behaviour, their interaction and relations with their students. The teachers' identity as male or female is closely related to authority in the classroom and educators have expressed the concern that students often consider male teachers as authoritarian and female teachers as too soft and unable to control some undisciplined situations [36]. As we will see at a later point, our research study provides collects similar perceptions held by students and teachers in terms of the gender factor and classroom management.

\section{CONTEXTUALISED INVESTIGATION}

Taking into account the context of this investigation, in which recent legislative changes place high levels of importance on gender equity and performance management, our aim in this study is to conceptualise how individual male and 
female students and teachers perceive the effectiveness of their learning in relation to the gender of teachers. The exploration of student and teacher perceptions, then, is gauged around the questions as to whether male and female students work better and/or learn more with male or female teachers and whether differences are to be found at different academic levels.

\section{Samples and Procedures}

Using a questionnaire applied to teachers and students in English class at Primary, Secondary, A-Level equivalent and University stages we have studied the perceptions of each group with regards to the following teaching and learning preferences in English as a foreign language (T/LEFL):

Variable 1. Respondent's preference for male teachers and the incidence of this in T/LEFL

Variable 2. Respondent's preference for female teachers and the incidence of this in T/LEFL

Variable 3. Perception that male students prefer female English teachers.

Variable 4. Perception that female students prefer male English teachers.

School: Year:

Type of School (underline):

$$
\begin{aligned}
& 1=\text { compensatory } 2=\text { rural public } 3=\text { urban public } \\
& 4=\text { semi-private } 5=\text { private }
\end{aligned}
$$

$\mathrm{N}^{\mathrm{o}}$ list: ........ Sex: M ..... F....... Date:
Express your opinion on the influence of the following aspects on students' learning.

\section{QUALITATIVE PART}

What influence does the gender of the teachers have on the way they act in English class? ................

Who are better, male teachers or female teachers? Who obtains better results in English class?

\section{QUANTITATIVE PART}

Now express your opinion on the following using this scale:

4 = always 3 = almost always 2 =sometimes 1 =hardly ever $0=$ never

1. Male English teachers are better than female teachers and you learn more with them (....)

2. Female English teachers are better than male teachers and you learn more with them (....)

3. Boys work better with female teachers than with male teachers and learn more with them (....)

4. Girls work better with male teachers and learn more with them (...)

The questionnaires were applied in a total of 18 voluntary participating institutions in the south of Spain and included 459 student respondents and 35 teacher respondents (Tables 1 and 2).

\begin{tabular}{|c|c|c|c|c|c|}
\hline School / University & Area & Year* & Male & Female & TOTAL \\
\hline Formación Profesional & Osuna (Seville) & $3^{\circ} \mathrm{ESO}$ & 5 & 9 & 14 \\
\hline I.B. "Incla Garcilaso" & Montilla (Córdoba) & $3^{\circ} \mathrm{ESO}$ & 21 & 12 & 33 \\
\hline I.B. "Padre Suárez" & Granada & $3^{\circ} \mathrm{ESO}$ & 13 & 15 & 28 \\
\hline I. B. "Inca Garcilaso" & Montilla (Cordoba) & $2^{\circ} \mathrm{ESO}$ & 20 & 12 & 32 \\
\hline Victoria Eugenia & Granada & $1^{\circ} \mathrm{ESO}$ & 8 & 21 & 29 \\
\hline I.E.S. "C. José Cela" & Granada & $3^{\circ} \mathrm{ESO}$ & 12 & 13 & 25 \\
\hline C.P. "L. Marillach" & Granada & $6^{\circ}$ E. P. & 7 & 5 & 12 \\
\hline Amor de Dios & Granada & $4^{\circ} \mathrm{ESO}$ & 13 & 15 & 28 \\
\hline Dulce N. de María & Granada & $6^{\circ}$ E.P. & 19 & 6 & 25 \\
\hline Dulce N. de María & Granada & $2^{\circ} \mathrm{ESO}$ & 28 & 3 & 31 \\
\hline Dulce N. de María & Granada & $4^{\circ} \mathrm{ESO}$ & 17 & 4 & 21 \\
\hline I.B "F. J. Burgos" & Motril (Granada) & $4^{\circ} \mathrm{ESO}$ & 13 & 17 & 30 \\
\hline Faculty of Education & Granada & $2^{\circ}$ and $3^{\circ}$ & 6 & 39 & 45 \\
\hline \multicolumn{3}{|l|}{ Total } & 233 & 226 & 459 \\
\hline
\end{tabular}

Table 1. Descriptive Statistics for Students

*The standard age at the beginning of educational stage is as follows: $11\left(6^{\circ} \mathrm{EP}\right) ; 12\left(1^{\circ} \mathrm{ESO}\right) ; 13\left(2^{\circ} \mathrm{ESO}\right) ; 14\left(3^{\circ} \mathrm{ESO}\right) ; 15\left(4^{\circ} \mathrm{ESO}\right) ; 17\left(2^{\circ} \mathrm{Bach}\right) ; 19$ and 20 respectively $\left(2^{\circ} \& 3^{\circ}\right)$ 
For the quantitative data, after calculating mean scores and standard deviation, we calculated the reliability of the scales employed in the questionnaire using Cronbach alpha. We also performed a T-Test in order to examine significant differences based on the gender of respondents. In the analysis of the open questions, we examined the textual responses in order to identify recurring patterns which could shed further light on the results obtained in the closed questions and extracted sample texts which exemplified opinions which indicated that differences did exist in the effectiveness of male or female teachers.

\section{RESULTS}

\section{Quantitative Data}

The mean values, the standard deviations and the analysis of variance in relation to the variable of gender provided by students are reflected in Table 3. Using Cronbach alpha, we found a high degree of reliability ( $a=0.88$ in the scale of the questionnaire applied to students and $a=0.78$ in the scale employed to teachers).
In terms of the students' own preference of teacher gender and their opinion of learning (Variables 1 and 2) it can be observed that scores at different academic levels were fairly homogenous and that there were no statistically significant differences. At all levels, however, there was a preference for female teachers; this was particularly manifest at primary school level. In terms of the opinion that boys and girls work better with teachers of the opposite gender (Variables 2 and 3 ) we can see, with the exception of the minimal difference expressed at primary school level, that all groups showed that the belief that 'female students work better with male teachers' was not as high as the belief that 'male students work better with female teachers'.

The comparison between the preferences of students grouped by gender (i.e. the opinion of boys and girls with regards to male and female teachers) and the assessment they give of gender is summarised in Table 4.

If we examine Variables 3 and 4, we can see that male students tended to believe that there was greater preference for teachers from the opposite sex in contrast to female stu-

Table 2. Case Summary of Teacher Sample

\begin{tabular}{|c|c|c|}
\hline Teachers & $\mathbf{N}$ & $\%$ \\
\hline Marginal area school & 2 & 2.9 \\
\hline Rural public school & 5 & 14.3 \\
\hline Urban public school & 20 & 57.1 \\
\hline University & 6 & 17.1 \\
\hline \multicolumn{3}{|l|}{ Academic levels } \\
\hline $3^{\text {rd }}$ Cycle Primary (Equivalent to UK years $6 \& 7$, K.S. 2-3) & 9 & 25.7 \\
\hline $1^{\text {st }}$ Cycle ESO (Equivalent to UK years $8 \& 9$, K.S. 3 ) & 7 & 20 \\
\hline \multicolumn{3}{|l|}{ Gender } \\
\hline Male Teachers & 17 & 48.6 \\
\hline Female Teachers & 18 & 51.4 \\
\hline \multicolumn{3}{|l|}{ Age } \\
\hline $20-30$ & 7 & 20 \\
\hline $31-40$ & 15 & 42.9 \\
\hline $41-50$ & 12 & 34.3 \\
\hline
\end{tabular}


Table 3. Students' Preference for Teacher Gender Depending on Academic Levels

\begin{tabular}{|c|c|c|c|c|c|c|c|c|c|c|c|c|c|}
\hline \multicolumn{2}{|r|}{ Variables } & \multicolumn{2}{|c|}{ Primary } & \multicolumn{2}{|c|}{ ESO (1) } & \multicolumn{2}{|c|}{$E S O$ (2) } & \multicolumn{2}{|c|}{ Bachillerato } & \multicolumn{2}{|c|}{ University } & \multicolumn{2}{|c|}{$A N O V A$} \\
\hline V2. & $\begin{array}{l}\text { Preference for female teachers } \\
\text { and incidence in T/LEFL. }\end{array}$ & 1.20 & .94 & 1.37 & .80 & 1.96 & .73 & 1.00 & .14 & .96 & .20 & .97 & .44 \\
\hline V4. & $\begin{array}{l}\text { Girls' preference for male } \\
\text { teachers. }\end{array}$ & 1.33 & .59 & 1.13 & .80 & 1.55 & .40 & 1.05 & .35 & .93 & .35 & .89 & .48 \\
\hline
\end{tabular}

Table 4. Students' Preference for Teacher Gender Depending on Student Gender

\begin{tabular}{|c|c|c|c|c|c|c|}
\hline \multirow[t]{2}{*}{ Variables related to gender } & \multicolumn{2}{|c|}{ Boys } & \multicolumn{2}{|c|}{ Girls } & \multicolumn{2}{|c|}{$T-T E S T$} \\
\hline & Mean & $S D$ & Mean & $S D$ & $t$ & Sig. ${ }^{*}$ \\
\hline V1. Preference for male teachers and incidence in T/LEFL & 1.45 & .74 & .63 & .46 & 2.78 & .01 \\
\hline V2. Preference for female teachers and incidence in T/LEFL & 1.64 & .93 & 1.13 & .70 & 1.45 & .26 \\
\hline V3. Boys' preference for female teachers & 1.91 & 1.10 & 1.18 & 61 & 1.61 & .12 \\
\hline V4. Girls' preference for male teachers & 1.34 & .74 & 1.19 & .56 & .37 & .71 \\
\hline
\end{tabular}

*In bold, values of $\mathrm{p}$ equal or lower than 0.05 .

dents, who considered that the same preference existed for both genders. Furthermore, if we look at the absolute values of the mean scores, it appears that both boys and girls believed that female teachers were better than male teachers and that they learnt more with this group (Variables 1 and 2).

Yet where statistically significant differences lie between boys and girls is in variable 1 (Male teachers are better than female teachers and you learn more with them). Using the TTest procedure we have obtained a value of $\mathrm{t}=2.78$ and a confidence level of $p=0.01$. There is a significant difference between how male and female students viewed male teachers, with the latter group attributing male teachers with a much lower score. The perceptions of teachers with regards to the incidence of the gender factor in T/LEFL are shown in Table 5
Using the T-Test procedure, we also found there to be significant differences between male and female teachers with regards to variables 1 (Preference for male teachers and incidence in T/LEFL) and also variable 2 (Preference for female teachers and incidence in T/LEFL). In both cases, there is a visibly greater tendency of male teachers to value the importance of these factors in comparison to female teachers, who did not agree with this type of statement and who believed in equality despite gender differences.

In the following graph (Fig. 1) we compare the opinions of students and teachers of both genders and represent their perceptions based on the absolute values of the mean scores:

Taking the absolute values of the mean scores, it can be observed that there is a clear difference between male teachers and students and female teachers and students. In the first

Table 5. Teacher Perception of Gender Factor

\begin{tabular}{|c|c|c|c|c|c|c|}
\hline \multirow[t]{2}{*}{ Variables related to gender } & \multicolumn{2}{|c|}{ Male teachers } & \multicolumn{2}{|c|}{ Female teachers } & \multicolumn{2}{|c|}{$T-T E S T$} \\
\hline & Mean & $S D$ & Mean & $S D$ & $T$ & Sig. ${ }^{\text {a }}$ \\
\hline V1. Preference for male teachers and incidence in T/LEFL & 1.35 & .86 & .61 & .85 & 2.56 & .01 \\
\hline V2. Preference for female teachers and incidence in T/LEFL & 1.35 & .86 & .67 & .91 & 2.29 & .02 \\
\hline V3. Boys' preference for female teachers & 1.53 & .72 & .94 & 1.06 & 1.90 & .06 \\
\hline V4. Girls' preference for male teachers & 1.59 & .80 & 1.00 & 1.19 & 1.71 & .09 \\
\hline
\end{tabular}

${ }^{\mathrm{a}}$ In bold, values of $\mathrm{p}$ equal or lower than 0.05 . 


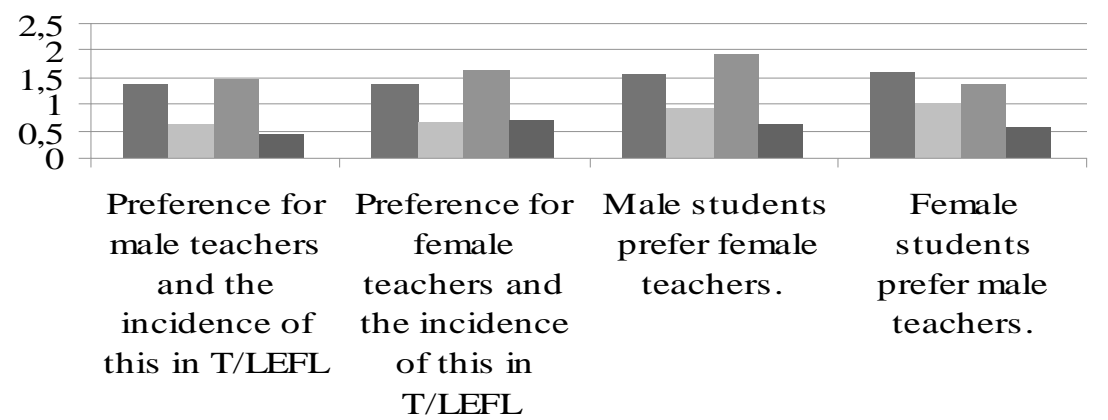

- Male teachers

Female teachers

- Male students

- Female students

\begin{tabular}{|c|c|c|c|}
\hline $\begin{array}{l}\text { Preference for } \\
\text { nale teachers } \\
\text { and the }\end{array}$ & $\begin{array}{l}\text { Preference for } \\
\text { female } \\
\text { teachers and } \\
\text { the incidence }\end{array}$ & $\begin{array}{c}\text { Male students } \\
\text { prefer female } \\
\text { teachers. }\end{array}$ & $\begin{array}{c}\text { Female } \\
\text { students } \\
\text { prefer male } \\
\text { teachers. }\end{array}$ \\
\hline
\end{tabular}

T/LEFL

Fig. (1). Summary of teacher and student perceptions of gender factor.

case, the male teachers and students considered the variable of gender to be more relevant and find more differences between men and women than the female subjects, whose mean scores are always much lower.

\section{Qualitative Data}

In terms of student responses, our textual analysis indicated there was a generally shared opinion at all levels that there were no real differences between male and female teachers, and that the teacher's ability to teach was considered to be more important. However, when differences were expressed, there were a number of students at primary and secondary levels who made observations which should be taken into account. A number of representative samples expressing these differences are provided below.

Translated Sample Responses from Primary School Students

S1 Men impose more respect; they control aggression better and they are more authoritarian.

S2 Male teachers get poorer results than female teachers.

S3 I think small children work better with female teachers.

S4 I like female teachers because they are more intelligent than male teachers.

Translated Sample Responses from Lower-to-Upper Secondary School Students

S5 Students prefer teachers of the same sex because they inspire more trust.

S6 Female teachers are nicer and friendlier and they understand boys better.

S7 Female teachers are better because they are more lenient.

S8 Male teachers are generally more respected and female teachers have to impose themselves in class from the first moment in order to gain respect.

As for teacher responses, the data provided by the open questionnaires also indicate that this group perceived very little difference between the teaching behaviour of male and female teachers. In general, they considered that the gender factor did not influence classes. Nevertheless, they also pointed to a number of differences which could prove to be interesting. Again, representative samples are given below.
Translated Sample Responses from Primary School Teachers

T1 Female teachers may inspire more trust than men. With regards to their performance in class, perhaps women are more attentive to diversity and to detail.

T2 The male teacher is given more respect than the female teacher in the majority of cases.

T3 Female teachers are better accepted by students either because they are women, they understand students better or because students sometimes consider them to be maternal figures.

T4 Sometimes, since in the family the one who gives the orders is the father, some students pay more attention to male teachers than to female teachers.

Translated Sample Responses from Secondary School Teachers

T5 Women may be more sensitive in recognising the emotional changes of students and give a greater sense of support.

T6 In some cases, the students obey female teachers less. In the case of university lecturers, gender differences related to authority appear to be less prevalent.

\section{Translated Sample Responses from University Teachers}

T7 Perhaps there are no differences, but some male students appear to be 'shier' with a female teacher.

T8 Some male students are usually more careful when they approach a female teacher and show themselves to be more spontaneous and at ease when they approach a male teacher.

T9 Girls...show themselves to be friendlier and try to "attract" more when they approach a male teacher; but when they approach a female teacher they do not use these strategies.

\section{DISCUSSION AND CONCLUSIONS}

The quantitative and qualitative data provided by the questionnaires which we have previously presented allow us to begin to respond to the questions and objectives of this study, which were to discover: a) whether students perceived to learn more in the English class with male or with female teachers; and b) if male and female students worked better with male or female teachers. 
Male and female teachers and male and female students coincide in expressing their belief that there is no great differences in the performance and functioning of the teacher in terms of gender. However, both male and female students concur in their own beliefs that they learn more with female teachers, a view which is not shared by teachers, who perceive no significant difference between genders. Nevertheless, when differences are stated, these tend to suggest that there is a perception that male teachers are more authoritarian yet obtain poorer results, while female teachers are more supportive, better accepted and obtain better results. Both teachers and students have highlighted certain differences caused by gender in class interaction: some boys are shier with female teachers and are more careful when they approach a female teacher. In the case of girls, it is possible that they try to gain the male teacher's attention.

Particularly with the quantitative results, it is also observed that boys tend to show a certain preference for female teachers, while the preference of girls for male teachers is less. There are also significant differences between male and female teachers in the variable which controls the preference of boys for female teachers and the preference of girls for male teachers. Both male teachers and male students believe that the preference for the opposite gender is a fact, as Lawrenz [20] indicated. In contrast, however, female teachers and female students in this study do not share this opinion and do not perceive this preference.

As we have already mentioned, it is interesting how both male teachers and male students consider the variable of gender to be more relevant and find more differences between men and women than female subjects. The two most important elements of our study, however, appear to be the fact that students believe that they learn more with female teachers; this is particularly true in the case of female students. At the same time they see a number of characteristics which are traditionally considered to be masculine (such as the imposition of respect and authority) in a negative light and highlight in positive terms the aspects of trust and acceptance associated in this study with the female teacher.

In a number of ways, the opinions expressed by the subjects in our study point to the continued existence of genderrelated patterns of teaching behaviour indicated in research conducted by Good et al. [24]. There is a perception that male teachers in the context in question appear to be more authoritarian and academically focused, while the female teachers are shown as being more supportive. Our reading of the qualitative and quantitative results obtained in our specific learning context suggest that the resulting sociopsychological environment stimulated by the presence of conscious or subconscious pedagogical strategies employed by teachers may have led to the students' perception that they learn more with female rather than with male teachers. This stands in contrast to previous studies which have indicated that both male and female students prefer to learn with teachers of the opposite sex. While the subjects in our study often pointed to the fact that male teachers were able to have more authority in class, this did not mean that students felt they learned more with them; indeed, it appears that the opposite is the case.

In a study carried out by Jules and Kutnick [38], one of the key aspects of good teaching lay in the quality of the teacher-student relationship; our study would suggest that the quality of this relationship in our context is perceived to be higher with female teachers than with male teachers. Among the possible factors which may contribute to this situation, and which have been detected in the qualitative part of our study, is the belief that female teachers are regarded as being less strict, are closer to the students and more attentive to their individual needs.

In their treatment of underachievement in boys in the UK, Younger, Warrington and Williams [31, p.339] suggest that there should be a greater deal of implementation of pedagogical strategies in the education of boys 'which foster more discussion and collaboration in the classroom, and which support cooperative and interactive teaching and learning'. In our context, we have found that both male and female students tend to feel more comfortable in such learning contexts which are less strict and authoritarian. To a large degree, this coincides with conclusions made by Maher [2], who, in attributing female teachers with qualities which more readily enable them to provide supportive environments, states:

It becomes clear that these qualities and practices are in fact extremely important, but not because they are natural and instinctive; caring must be learned. And they are not "soft," not the "opposite" of, or at another extreme from, academic rigor. Rather, they are a central quality of a demanding and successful teacher, whether male or female.

[2, p. 113]

There are obvious limitations to what we are able to conclude from the research which we have undertaken. The most important of these, in our view, is the fact that the student perceptions are, by nature, subjective, and are not supported by quantitative external evidence to suggest that more learning does, indeed, take place with female teachers. At the same time, this subjective opinion is not shared by the teachers themselves. Nevertheless, the fact that students do express that they learn more with female teachers in itself may constitute an indirect indicator of student preferences for certain teaching styles and learning environments.

If we are to accept existing evidence which suggests that positive learning environments go hand in hand with positive learner performance [39] and if we are to draw any pedagogical conclusions from this study, we would tentatively state that there are indications that a number of attitudes adopted and strategies employed by female teachers in this specific context seem to enhance the socio-psychological environment which may lead to higher levels of satisfaction with the learning process. Whether or not students actually learn more with female teachers in our context is a question which requires further research.

While much of what we have concluded with regards to the learning environment may seem obvious, other aspects of our study, such as the rejection of the hypothesis that students, both male and female, prefer teachers of the opposite sex, are perhaps, not as common. In either case, we feel that it is worthwhile to bring these issues and perceptions to the attention of practising teachers particularly in our own context in the hope is that it will provoke self-questioning, examinations of practice, changes in patterns of instructional 
behaviour where appropriate, and further investigation into the effects of gender on teaching and learning.

On a final note, we would mention that as we enter new stages of quality control, target-setting and the measurement of global performance figures, it is important that certain beneficial instructional qualities are not obviated and that control is not equated with authoritarianism and individualism. Instead, we must continually remind ourselves of the need for more democratic, understanding and cooperative forms of teaching and learning in which positive environments are not sacrificed in the quest for obtaining everincreasing demands on performance.

\section{REFERENCES}

[1] Dillabough J. Gender politics and conceptions of modern teacher: women, identity and professionalism. Br J Sociol Educ 1999; 20: 373-94.

[2] Maher, Frances A. Gender and Teaching. Lawrence Erlbaum Associates: Mahwah, NJ 2002.

[3] Forrester G. All in a day's work: primary teachers 'performing' and 'caring'. Gend Educ 2005; 17: 271-87.

[4] Mahony P, Hextall I, Menter I. Threshold assessment and performance management: modernizing or masculinizing teaching in England? Gend Educ 2004; 16: 131-49.

[5] McAuliffe S. Toward understanding one another: second graders' use of gendered language and story styles. Read Teach 1994; 47 : 302-10.

[6] Kamler B. Constructing gender in the process writing classroom. Lang Arts 1993; 70: 95-103.

[7] Evans K. Creating spaces for equity? The role of positioning in peer led literature discussions. Lang Arts 1966; 73: 194-202.

[8] Gass S, Varonis E. Sex differences in non-native speaker-nonnative speaker interaction. In: Day R, Ed. Talking to learn: conversations in second language acquisition, Newbury House, Rowley, Mass 1986; pp.327-52.

[9] Davis B. Gender bias in school text books. Commonwealth Secretariat. London 1995.

[10] Sheldon J. Gender stereotypes in educational software for young children. Sex Roles 2004; 51: 433-44.

[11] Leskin J. Determining social prominence: a methodology for uncovering gender bias in ESL textbooks. In: Hall D, Hewings A, Eds. Innovation in English language teaching: a reader, Routledge, New York 2001; pp. 275-83.

[12] Manjari S. Gender issues in the language arts classroom. Eric Digest. 1998. Accessed 21 April, 2009. Available from http://www.ericdigests.org/ 1999-3/issues.htm

[13] Streitmatter J. Toward gender equity in the classroom: everyday teachers' beliefs and practices. State University of New York Press. New York 1994.

[14] Alverman D, Commeyras M, Young J, Hinson D, Randall S. Interrupting gendered discursive practices in classroom talk about texts: Essay to think about, difficult to do. Athens, Georgia: National Reading Research Center 1996.

[15] Commeyras M, Young J, Hinson D. Educators stances toward gender issues in literacy. Paper presented at the Annual Meeting of the American Educational Research Association, 1997 March; Chicago, Illinois, 1997.

[16] Wilkinson LC, Marret CB. Gender influences in classroom interaction. New York: Academic Press. New York 1985.
[17] Brophy J. Interactions of male and female students with male and female teachers. In: Wilkinson LC, Marret CB, Eds. Gender influences in classroom interaction, Academic Press New York 1985; pp. 115-42.

[18] Meece JL. The influence of school experiences on the development of gender schemata. In: Liben LS, Signorella ML, Eds. Children's gender schemata. Pennsylvania State University. San Francisco 1987; pp. 57-73.

[19] Baumert J. Koedukation oder, geschlechtertrennung. Zeitschrift für pädagogik 1992; 38: 83-110.

[20] Lawrenz F. Gender effects for student perception of the classroom psychosocial environment. J Res Sci Teach 1987; 24: 689-97.

[21] Hopf D, Hatzichristou C. Teacher gender-related influences in Greek schools. Br J Educ Psychol 1999; 69: 1-18.

[22] Ritter DR. Teacher's perceptions of problem behavior in general and special education. Except Child 1989; 55: 559-64.

[23] Jones, MG, Wheatley, J. Gender differences in teacher-student interactions in science classrooms. J Res Sci Teach 1990; 27: 86174.

[24] Good TL, Sikes JN, Brophy JE. Effects of teacher sex and student sex on classroom interaction. J Educ Psychol 1973; 65: 74-87.

[25] Younger M, Warrington M. Differential achievement of girls and boys at GCSE: some observations from the perspective of one school. Br J Sociol Educ 1996; 17: 299-314.

[26] Arnot M, David M, Weiner G. Educational Reforms and Gender Equality in Schools. Equal Opportunities Committee. Manchester 1996.

[27] Turner E, Riddell S, Brown S. Gender equity in Scottish schools: the impact of recent educational reforms. Equal Opportunities Commission. Manchester 1995.

[28] Riddell S. Boys and under-achievement: the Scottish dimension. Inter J Inclu Educ 1998; 2: 169-86

[29] Harris S, Nixon J, Rudduck J. Schoolwork, homework and gender. Gend Educ 1993; 5: 3-15.

[30] Rudduck J, Chaplain R, Wallace G. School improvement: what can students tell us? David Fulton. London 1995.

[31] Younger M, Warrington M, Williams J. The gender gap and classroom interactions: reality and rhetoric? Br J Sociol Educ 1999; 20: 325-41.

[32] Gipps C. Review and conclusions: a pedagogy or a range of pedagogic strategies? In: Murphy PF, Gipps CV, Eds. Equity in the classroom: towards effective pedagogy for girls and boys, Falmer Press. London 1996; pp. 260-71.

[33] Williams M, Burden R, Lanvers U. 'French is the language of love and stuff': student perceptions of issues related to motivation in learning a foreign language. Br Educ Res J 2002; 28: 503-28.

[34] Burstall C. Factors affecting foreign language-learning: a consideration of some relevant research findings, Language Teaching and Linguistics Abstracts. 1975; 8: 105-25.

[35] Head J. Gender identity and cognitive style. In: Murphy PF, Gipps $\mathrm{CV}$, Eds. Equity in the classroom: towards effective pedagogy for girls and boys, Falmer Press. London 1996; pp. 59-70.

[36] Ropers-Huilman B. Constructing feminist teachers: complexities of identity. Gend Educ 1997; 9: 327-43.

[37] Weiler K. Women teaching for change: gender, class and power. Bergin and Garvey. New York 1988.

[38] Jules V, Kutnick P. Student perceptions of a good teacher: the gender perspective. Br J Educ Psychol 1997; 67: 497-511.

[39] Haertel GD, Walberg HJ, Haertel EH. Socio-psychological environments and learning: a quantitative synthesis. Br Educ Res J 1981; 7: 27-36. 